\title{
Technical-urbanistic infrastructure in the Romanian Danube Valley. Urban vs. rural territorial disparities
}

\author{
Bianca MitricăA*, Nicoleta Damian ${ }^{\mathrm{B}}$, Irena MocanuA, Paul ŞerbanA ${ }^{A}$, Radu SăgeatăA \\ Received: June 15, 2016 | Revised: December 5, 2016 | Accepted: December 20, 2016
}

\begin{abstract}
Infrastructure, particularly technical one, is basis of economic activities both in urban and rural areas. The Romanian sector of the Danube Valley covers a large area, in which the life of resident communities is shaped by the River (1,075 km long). At present, 266 local administrative units (LAU2) in the Romanian Danube Valley number 238 communes, 28 municipia and towns and a population of 1.7 million inhabitants. The study relies on the data provided by the National Institute of Statistics, the results of the Population and Housing Census (2011) and TEMPO Online Database (Internet 1). Hierarchizing LAU2 in terms of the technical-urbanistic infrastructure was made by the Hierarchical Ascending Classification (HAC). The aim was to group together territorial-administrative units by their parametric variables. There are many Danube Valley communities still unconnected to local drinking-water and sewerage systems, a restrictive factor in drawing potential investments into local economies. The study points out that the large Danubian port-cities also have the longest water and natural gas supply networks, as well as the greatest proportion of dwelling-houses connected to these systems. A fairly good situation have also some rural settlements lying close to big municipia or to tourist towns (in Danube Gorge and Danube Delta).
\end{abstract}

Keywords: technical-urbanistic infrastructure, territorial disparities, urban, rural, Romanian Danube Valley.

\section{Introduction}

When it comes to public services, utility is a term that signifies a public service, the two notions being often used one for the other. However, the term utilities designate that category of services that have often an obvious material component, the very nature of this category implying a specific infrastructure. Major utilities: electrical energy, thermal energy, natural gas, the management of household/urban wastes, water supply, sewerage network, telecommunications, etc. (Androniceanu, 2002; Plumb, et al., 2003). The techni- cal-urbanistic infrastructure represents a major component of development resources, both in town and the countryside, because it directly affects the quality of life. Infrastructure, particularly the technical one, is the basis of economic activities in the urban and the rural alike. It has a huge impact on the scope, structure, and spatial distribution of economic activity. Its level of development has a substantial effect on the attractiveness or unattractiveness of particular areas, the inflow of capital resources and, thus, the creation of new workplaces. It is also one of the most im-

\footnotetext{
A Human Geography and Regional Development Department, Institute of Geography, Romanian Academy, Bucharest, Romania; Dimitrie Racoviță Str., no. 12, secor 2, 023993, Bucharest, Romania; biancadumitrescu78@yahoo.com, mocanitai@yahoo.com, paulrazvanserban@yahoo.co.uk, radu_sageata@yahoo.com

B Environmental Geography and GIS Department, Institute of Geography, Romanian Academy, Bucharest, Romania; Dimitrie Racoviță Str., no. 12, secor 2, 023993, Bucharest, Romania; nicoleta_damian2002@yahoo.com

* Corresponding author: Bianca Mitrică, e-mail: biancadumitrescu78@yahoo.com
} 
portant conditions for improving the living standards of the population and is the basis of social organization (Gadysz, 2009).

As one of the most important overhead capital of urban economics and social development, the sustainable development of urban infrastructure is becoming a key issue of prosperous society growing (Zhou, Liu, 2015).

Activities relating to local public utilities are extremely socially important, being substantially involved in the sustainable development of localities and the improvement of living conditions, in general and of residential ones, in particular (Lieske et al, 2015). The assessment of dwelling quality, associated with the quality and quantity of the technical infrastructure, is discussed in several studies. Voicu and Voicu (2005) have published an descriptive article about access to utilities (e.g. hot water, sewerage, electricity, natural gas), differentiated by some factors such as socio-economic status, geographical location, type of residence. The post-adhering to European Union diagnosis of housing conditions in Romania represents the topic of a study highlighting the precariousness of housing quality as the main element of the quality of life (Vâlceanu, Tămârjan, 2011). Vâlceanu and Zulaica (2012) have used Housing Quality Index (HQI) as analysis tool of urban housing and its assessment of the quality, the statistical analysis being correlated with social research methods and territorial identification of the main failures of housing contributing to the urban zoning areas. Antonescu (2014) approached housing as a fundamental aspect of modern society, an indicator of standard of living and prosperity.

Public utility services should meet some basic demands: universality; qualitative and quantitative continuity, adaptability to the users' demands and longterm management; equal and indiscriminate access to the public service; transparency and protection of users (Negruţ, 2008).

As part and parcel of the tertiary sector, public services contribute to increasing the share of this sector in the Romanian economy, being subject to the particularities of any services category, such as: intangibility, non-division, heterogeneity, perishability and non-sustainability (Babucea, Rabonţu, 2015).

Research into the quality of life and the living standard also emphasizes that water plays an important role in the daily life of the population (ENVIS Centre on Human Settlements, 2009; Eberhardt, Pegram, 200o; Chiriac, et al., 2001; WQEHH, 2008; CWHW, 2010; Policy Brief on Water Quality, 2011; Koeck, 2012), improving the public health protection (Qilin, et al., 2009; Water Ouality of Ecosystems and Human Health, 2008), reducing the child mortality (Günther, Günther, 2011; Mitrică, Mocanu, 2011).
Public water supply and sewerage services are among these utilities of general public interest. The EU Green Paper has introduced the concept of a partnership between the different levels of governance in Europe, considering that public services of general economic interest are paramount in maintaining social cohesion, improving the quality of life and securing sustainable development (www.ec.europa.eu/greenpapers).

The Romanian Danube Valley is an integral part of the Danube Region. The sustainable framework of policy integration and coherent development of the territory is provided by the EU Strategy for the Danube Region (EUSRD), which sets out priority actions to make the Danube Region a competitive EU region for the 21st century (Internet 2). Two of the four pillars of the EUSDR ('Protecting the environment' and 'Building prosperity') refer to a topic of great importance not only for the Danube Region, but also for Europe 2020, as a whole.

Analysing some of the characteristic technical-structure indicators is aimed at calculating the composite index of sustainable development in the territory in the framework of the Romania's Territorial Development Strategy, 2020-2035 elaborated by the Ministry of Regional Development and Public Administration (e.g. the ratio of dwellings connected to drinking-water and sewerage networks, which is an indicator of the level of public services in a community, a basic prerequisite for habitation and economic activities). Natural gas supply to households could be an indicator of the extent to which development is sustainable, because of all the heat-supply methods used in Romania, natural gas is the most environmentfriendly one; the level of natural gas consumption is an indicator of its use compared to other fuels, and of dwelling quality, as well (Romania's Territorial Development Strategy, 2020-2035, 2015).

The main goals of developing the infrastructure of public utilities, in conformity with the provision of the EU Directives, have in view water supply, sewerage disposal, heat, natural gas and electricity supply, and the creation of green areas (Regional Development Plan for the South-Muntenia Development Region 2014-2020, 2015; Regional Development Plan for the West Development Region 2014-2020, 2015).

Looking at the population's life-style should necessarily take into account the urbanistic infrastructure of settlements and residences, basically the main public utilities, e.g. drinking-water networks, systems of waste water dispersal, natural gas delivery for heating and cooking, and electricity consumption. In this regard, most settlements in Romania, and in the Danube Valley, especially the rural ones, do not meet the required standards. 
The issue of the technical-urbanistic infrastructure of settlements and households calls for a wide-ranging approach to outline the numerous socio-cultural, demographic and economic implications of benefitting from it. The technical-urbanistic infrastructure is a major indicator of the level of civilization in an area and of development opportunities for the respective human communities. Research into the quality of life and of living standard (Teodorescu, 2005) also emphasizes that the technical-urbanistic infrastructure plays an important role in the daily life of the population (Chiriac, et al., 2001; Vasile, et al., 2010; Mocanu, et al., 2011).

The relationship between the settlement network and the technical-urbanistic infrastructure of localities and households bears heavily on community exclusion. Poverty in the rural areas is rather locationdependent. Thus, the villages lying at great distances from the county-seat, and from the European highways, with an economy and labour employment based on agriculture, are underdeveloped (Pop, 2004; Mocanu, et al., 2011, Damian, 2013).

This paper aims to address territorial disparities in terms of technical infrastructure quality in rural and urban residences by empirically examining some relevant available statistical variables and indicators of the local administrative units (LAU2). It also makes a hierarchization (using the Hierarchical Ascending Classification method (CAH) of the Danubian rural and urban settlements in terms of the level of their technical-urbanistic infrastructure. The first sections of the paper deal with some determinant quality factors of the technical infrastructure (e.g. physical-geographical, political, and economic), also referring to data-sources; the next sections focus on methodological aspects, and discuss the results of this study.

\section{Study-area}

The Romanian sector of the Danube Valley covers a large area in which the life of resident communities is shaped by the River (1,075 km long). The Romanian Danube Valley includes part of four development regions (West, South-West Oltenia, South Muntenia and South-East Dobrogea) and twelve counties (Caraş-Severin, Mehedinţi, Dolj, Olt, Teleorman, Giurgiu, Călăraşi, Ialomiţ̧a, Constanţa, Brăila, Galaţi and Tulcea). At present, the 266 local administrative units (LAU2) in the Romanian Danube Valley number 238 communes, 28 municipia and towns and a population of 1.7 million inhabitants (2014), from which $42.0 \%$ is rural and $58.0 \%$ is urban (Figure 1 ).

Most Danube Valley towns (19) fall into the smallsize category (under 20,000 inh.), Şegarcea (Dolj County) standing at the bottom of the table with only
3,657 inhabitants. The middle-size category (20,000100,000 inh.) includes 7 towns together with two large-size category (over 100,00o inh.), with Galaţi city being the largest $(249,423$ inhabitants). The population of the LAU2 goes from 542 in Padina commune (Tulcea County which encompasses the Danube Delta, a territory less favourable to the development of settlements) and 10,470 in Poiana Mare (Dolj County).

In the cross-border zone in the Romanian Danube sector; throughout the centuries, the river was both an important axis of structuring transversal fluxes and the main navigation thoroughfare, which favoured longitudinal fluxes between Central Europe and the Black Sea Basin. Its presence generated a real "urban belt" in the southern part of this country, contributing to the development of a specific economic activity, thereby increasing the polarization potential of port towns. The latter is closely related to connecting harbours to the land transport system, and to some towns acting as customs points (Săgeată et al, 2010, Săgeată, Persu, 2013).

The negative population dynamics $(20 \%)$ over $1992-$ 2011 reveals the deep-seated crisis in this area, both in the rural and the urban, especially in case of small and middle towns, numerous demographic aspects correlating with the economic and social situations (Dumitrescu, 2008, Vârdol, 2009).

The geography of the Romanian Danube Valley follows technical infrastructure quality and its disparities as a research topic of complex studies into the small Danubian towns (Vîrdol, 2009), or of some comprehensive studies on the different development level of Romanian towns (Vîrdol, 2008), or of those in the Romanian Danube Valley (Ianoş, 2000).

\section{Data and methodology}

The statistical data used assess the quality of the technical infrastructure in this study-area. The study relies on the data provided by the National Institute of Statistics, the results of the Population and Housing Census, 2011 and TEMPO Online Database, processed and mapped for $\mathrm{LAU}_{2}$ hierarchization in terms of the technical-urbanistic equipment level.

Relevant statistical data (length of the water-supply network and of the sewerage system, length of natural gas distribution pipes, drinking-water delivered, natural gas delivered, the percent of dwellings connected to the water-supply network and sewerage system) were processed in order to provide a comprehensive information on the quality of the Romanian Valley $\mathrm{LAU}_{2}$ infrastructure.

A LAU2 hierarchy of the level of technical-urbanistic infrastructure (Hierarchical Ascending Classification (HAC) method) grouped together territori- 


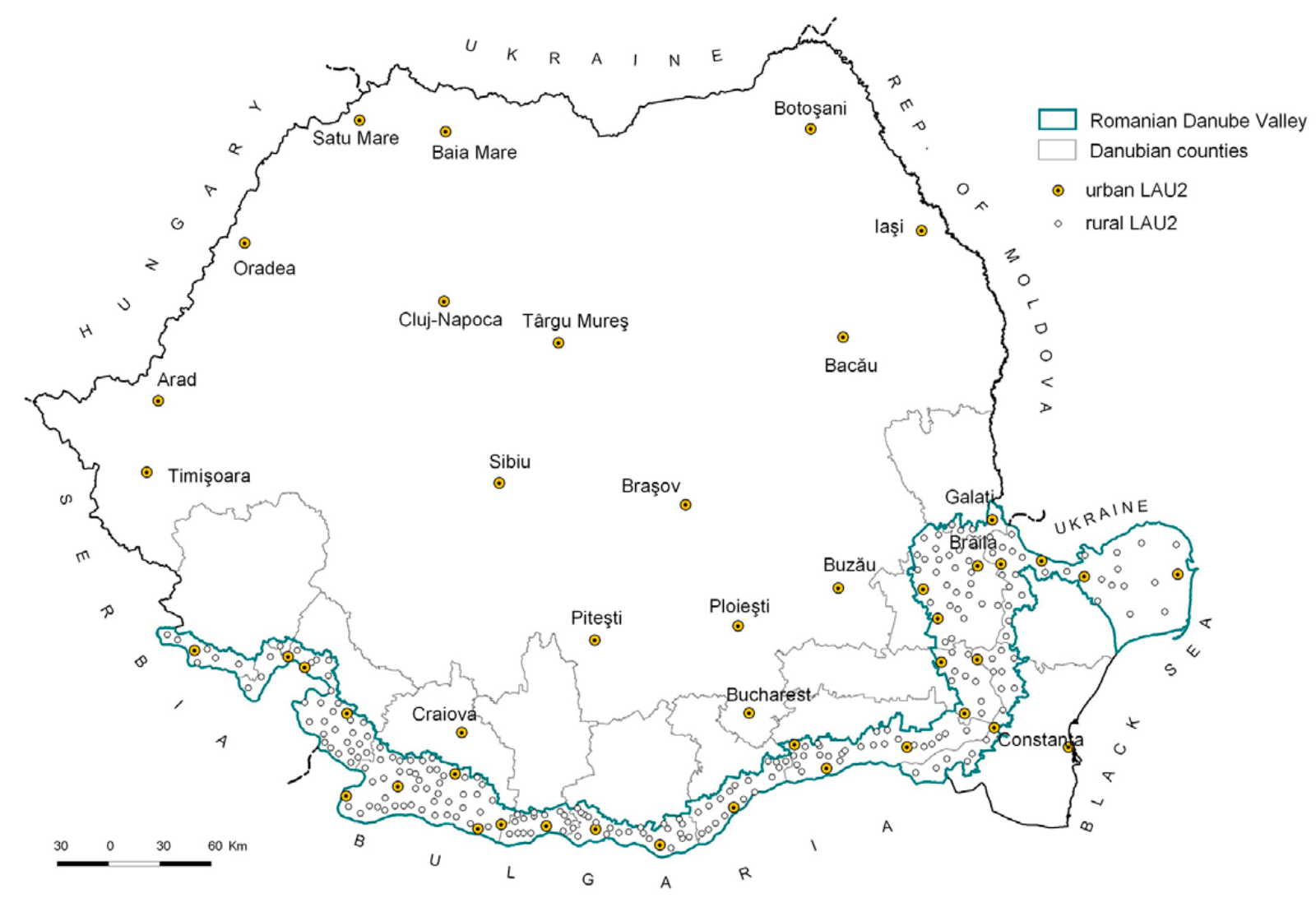

Figure 1. The geographical position of the Romanian Danube Valley

al administrative units (communes and towns in this case) in terms of parametric values. The administrative units, having similar parametric values were selected as representative, and included into one and the same class, forming thus a territorial typology.

In 1977, Bruynooghe observed that this data-exploration technique (HAC) enabled one to easily hierarchized accurately a vast number of data. Including administrative units into a specific class was made by the nearest neighbour method, distinguishing the classes implied the following algorithm: look for couples of neighbour elements within a set of objects to be classified so that each element of the couple should be nearest to the other element. Next, nearest neighbour elements are progressively gathered into a joined link. Finally, this method leads to the alternation of a similitude graph with the building of a binary tree through successive integrations, just like in the case of the successive graph method (Bruynooghe, 1977; Benzécri, 1982).

When using this data-exploration technique and looking at the class of ensuing variables, one's attention is drawn by the groups of value- based variables, otherwise said, of standard deviations from the general mean. Noteworthy, high-value variables, expressed in standard deviation from the mean, but occurring within one and the some class, are very likely to be found within the same main component.
By applying HAC to the five selected variables (drinking water delivered/inh. = L_WATER_INH_ DAY, natural gas delivered/inh. = CM_GASE_INH_ YEAR, the percent of dwellings connected to the water-supply network $=$ DWELL_WATER and the percent of dwellings connected to the sewerage system $=$ DWELL_SEWER, length of sewerage system = LENGTH_SEWER), five classes are obtained which represent as many LAU 2 typologies in the Romanian Danube Valley. The values of each variable were turned into standard deviations from the average variable of the study area.

HAC method helps us to get detail profile knowledge of the local administrative units. Once knowing what variables index imbalances the territorial development of the technical infrastructure, and also knowing its territorial spatial distribution (through HAC), would help decision-makers to focus their actions on a certain area.

\section{Results and discussion}

Supplying the population with drinking water is a basic prerequisite for its normal development and optimal hygienic conditions. Supplying drinking-water is also strictly necessary for discharging economic activities in town and countryside alike. In this country, $75 \%$ of the population are connected to the pub- 
lic drinking-water delivery system. Therefore, further efforts are required to increase this percentage and, at the same time, diminish losses in the old and wornout infrastructure.

According to EU membership, Romania commited itself to implementing (until 2015), the European Directives $98 / 83$ EC on the quality of drinking-water, and 91/271/EC (until 2018) on drinking-water demand the inspection of water-supply systems and the control of drinking-water quality. These provisions referred to settlements already connected to the watersupply systems and also to settlements with over 50 inhabitants that should have access to drinking-water of quality (Regional Development Plan for the SouthEast Development Region 2014-2020, 2015; Regional Development Plan for the South-West Oltenia Development Region 2014-2020, 2015). However, these commitments have only partly been fulfilled.

The particularities of the Danube Valley and a series of its characteristics highlight several LAU 2 features of the area's technical-urbanistic infrastructure.

The water supplied to the population comes either from a central source, or from local installations (wells, or from springs captured). In order to get an overview of the extent to which settlements and the population are connected to the drinking-water system let us take a look at the number of localities that have a distribution network, the length of the network, water consumption/capita and the percentage of dwelling-houses benefitting from a water-delivery system.

The situation of the Danube Valley settlements connected to drinking-water installations and the length of the network $(\mathrm{km})$ are shown in Table 1.

Out of the 266 settlements in the Romanian Danube Valley, 185, including the 28 towns, representing
$7.5 \%$ of all the country's localities and $8.6 \%$ of the population, were connected to the drinking-water supply system. The 82 communes (30.7\% of all LAU 2) were deprived of that facility, here is their distribution by county: Dolj 27 (32.9\%), Călăraşi 5 (6.1\%), Mehedinţi 12 (14.6\%), Olt and Giurgiu 11 each (13.4\%) and Teleor$\operatorname{man} 15(18.3 \%)$.

The drinking-water distribution network is the longest in Brăila County, next in line are the counties of Tulcea, Călăraşi and Galaţi (Figure 2).

Water-pipe length shows obvious disparities between the urban and the rural, also in terms of connection to the network, towns standing by far better than the countryside; the total simple length in towns is satisfactory and proportional to their demographic size, e.g. Galaţi - $572 \mathrm{~km}$, Brăila - $464 \mathrm{~km}$, as well as Drobeta-Turnu Severin, Tulcea and Giurgiu, with an average of $95.9 \mathrm{~km} /$ town. At the bottom of the table (under 50 $\mathrm{km})$ stand Şegarcea $(32.5 \mathrm{~km})$, Moldova Nouă $(33 \mathrm{~km})$ and Zimnicea $(34 \mathrm{~km}$ ) (Figure 2). Most of the $82 \mathrm{com}$ munes, where no water delivery pipes exist, lie in the counties of Dolj (27), Teleorman (15) and Mehedinţi (12). Pipe length in the countryside goes from $1.5 \mathrm{~km}$ to 50 $\mathrm{km}$, with an average of $14.8 \mathrm{~km} / \mathrm{commune}$. This substantial differentiation suggests either the development level of a commune, the beginning of network connection works, or that such works are underway.

All the Danube Valley LAU 2 settlements in the counties of Constanţa, Ialomiţa, Brăila and Tulcea were connected to the public drinking-water system.

According to the National Institute of Statistics (2014), the quantity of drinking-water delivered from the public network to LAU 2 consumers was of 47.3 billion litres, that is, $75.2 \mathrm{l} / / \mathrm{inh} /$ day. which is quite little compared to 100-200 litres in the EU countries

Table 1. Structure of LAU2 connected to the drinking-water system, 2014

\begin{tabular}{|l|c|c|c|c|}
\hline \multirow{2}{*}{ County } & \multicolumn{2}{|c|}{ LAU2 connected } & $\begin{array}{c}\text { LAU 2 } \\
\text { unconnected }\end{array}$ & $\begin{array}{c}\text { Network } \\
\text { length (km) }\end{array}$ \\
\cline { 2 - 5 } & urban & rural & 1 & 98.6 \\
\hline Caraş-Severin & 1 & 6 & 12 & 560.5 \\
\hline Mehedinți & 3 & 18 & 27 & 629.2 \\
\hline Dolj & 5 & 19 & 11 & 125.4 \\
\hline Teleorman & 1 & 4 & 15 & 187.9 \\
\hline Giurgiu & 2 & 6 & 11 & 256.7 \\
\hline Călăraşi & 1 & 6 & 4 & 793.9 \\
\hline Ialomița & 3 & 20 & 0 & 372.7 \\
\hline Constanța & 2 & 8 & 0 & 387.1 \\
\hline Brăila & 2 & 14 & 1 & $1,158.90$ \\
\hline Galați & 3 & 26 & 0 & 672.5 \\
\hline Tulcea & 1 & 3 & 0 & 965.8 \\
\hline TOTAL & 4 & 157 & & $6,209.20$ \\
\hline
\end{tabular}




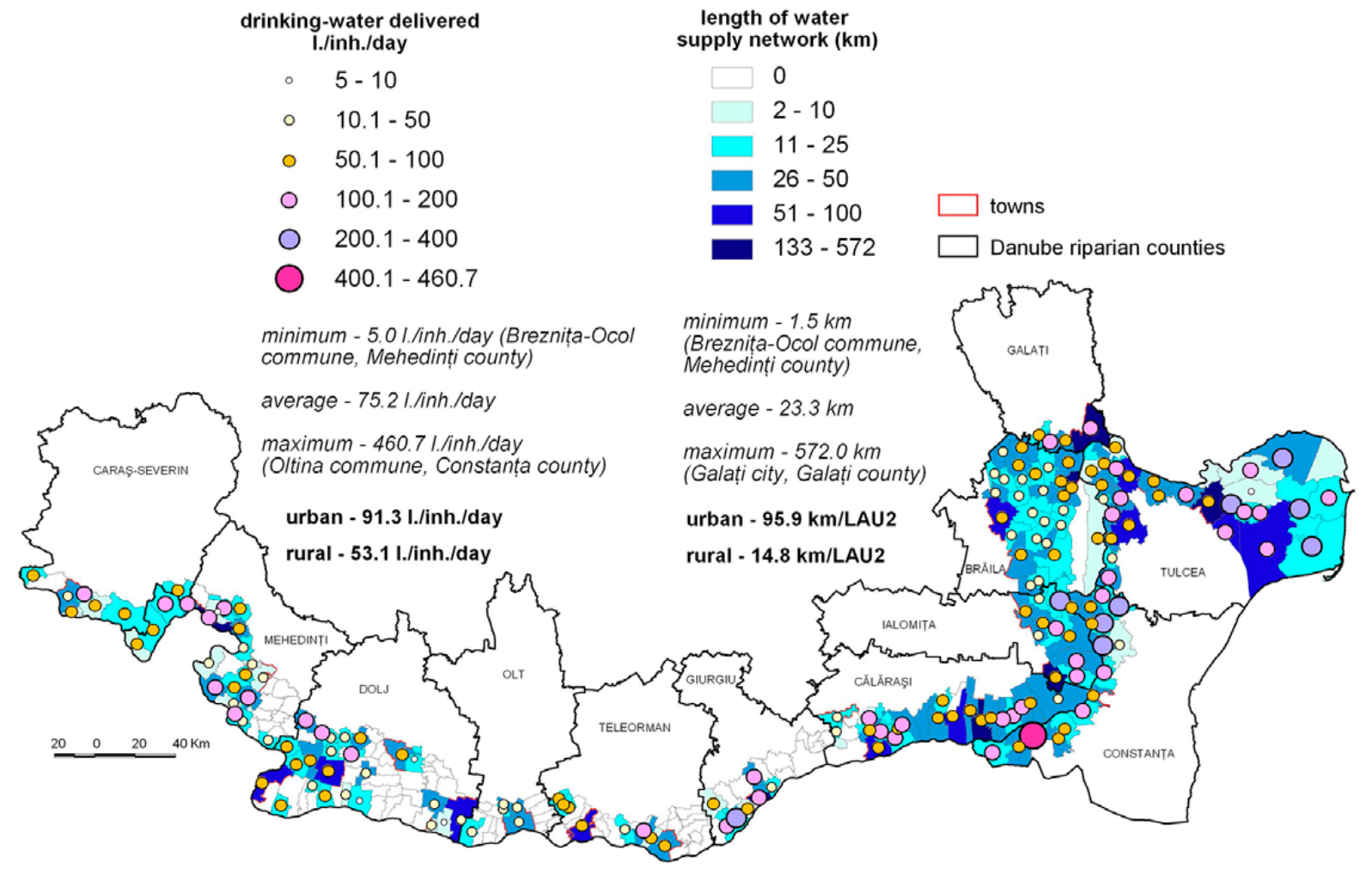

Figure 2. Drinking-water consumption and length of public distribution network (2014)

(optimum quantity 100 1/inh./day versus an average of 94 litres in Romania).

Referred to the total population, each $\mathrm{LAU}_{2}$ consumption values range from 50.1 to 460.7 1/inh./day, with an average value of 91.3 1/inh./day in the urban area and of 53.1 1/inh./day in the rural area. Apart from the 82 LAU 2 unconnected to the public drinking-water network, $84.2 \%$ of all Valley settlements rank below the optimum consumption level (Figure 2). It follows that only $15.8 \%$ of settlements meet the desired per capita standard.

The proportion of houses connected to the water supply systems varies between $0.9 \%$ in Oprişor commune and $98 \%$ in Drobeta-Turnu Severin town, both in Mehedinţi County (Figure 3). Compared to the national average (66.7\%), the Danube Valley has an average of $22.7 \%$ in the rural, and $88.1 \%$ in the urban. In most towns, over $70 \%$ of the houses have drinking water, but there are cases in which the percentage is under $30 \%$ (e.g. Budeşti $-26 \%$ and Însurăţei $28.5 \%$ ). Only 35 localities, out of a total of 266 , have over $50 \%$ of the houses connected to the drinkingwater and sewerage systems. A number of eight Olt County communes, marked by poor socio-economic development, have no in-door water supply.

As far as the drinking-water public distribution network is concerned, there are communes in some
Danube Valley counties in which network length is rather small, and the percentage of settlements unconnected to this supply system is fairly high in counties like Dolj, Giurgiu, Teleorman and Olt, themselves less-developed economically. On the other hand, a longer distribution network and a higher proportion of dwellings connected to the drinking-water system have several communes in Constanţa, Ialomiţa, Brăila, Galaţi and Tulcea counties. Noteworthy, greater efforts than in past years are underway for connecting as many rural dwellings as possible to the centralised drink-water system (Mocanu, et al., 2011).

Besides the poor development of the water-delivery infrastructure, the population of the Danube Valley (especially in settlements unconnected to the network) has to put up with the poor quality of water taken from wells (far below drinking-water standards.) The rural population, which does not benefit from a waterdelivery infrastructure, resorts to wells, which means dependence on fluctuating underground water flows, basically on weather conditions. In the droughty periods, wells may dry up, causing acute water shortage in many rural settlements. The year 2003, one of the driest in Romania, created a water crisis in the whole country, in the entire outer-Carpathian region, hence in Danube Valley areas, too, affecting especially parts of the Oltenia Plain (the prolonged drought lowered 


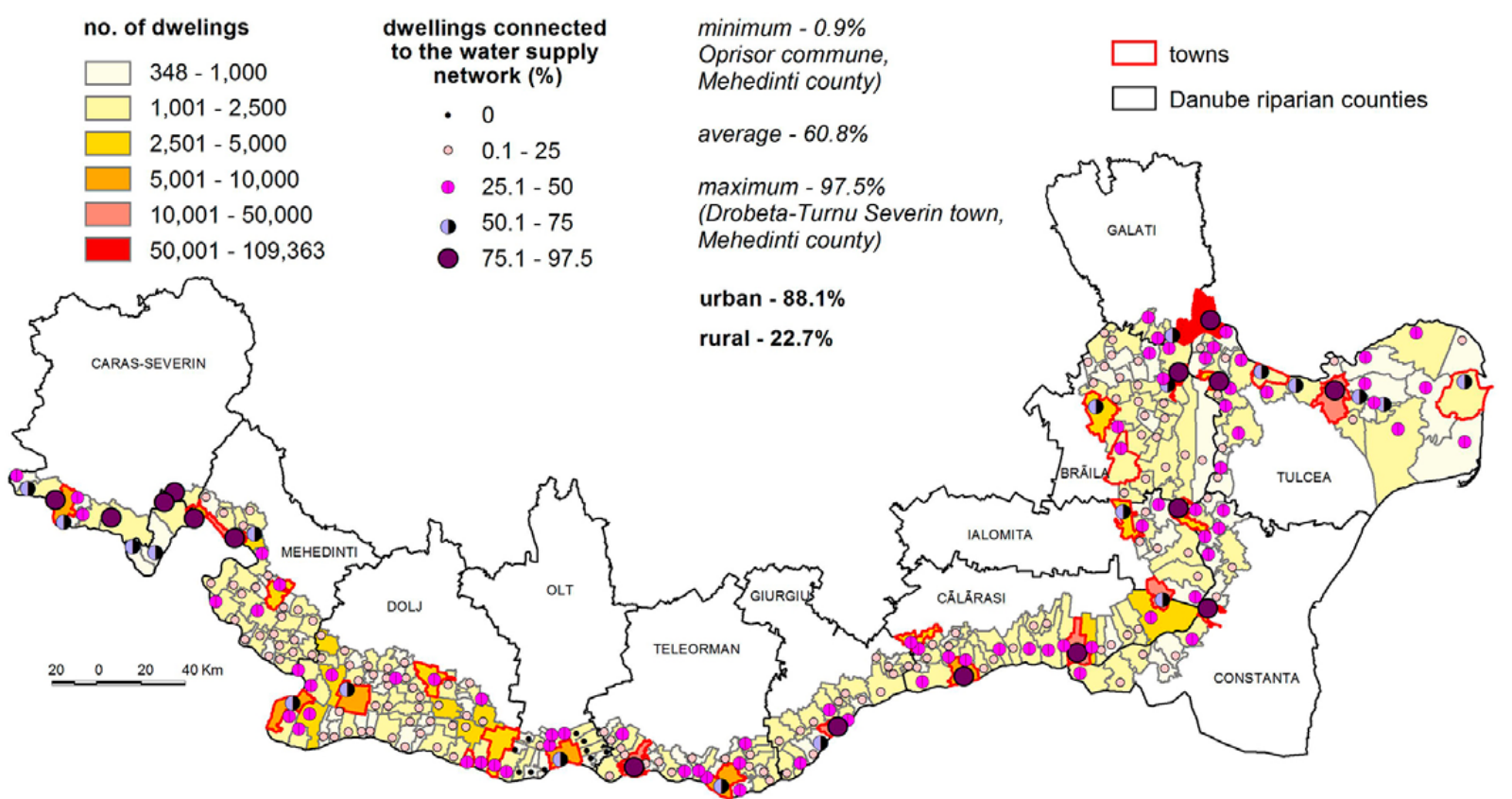

Figure 3. The dwellings connected to the drinking water supply network, 2014

the groundwater level by nearly 5 meters below average levels, and consequently many wells dried up) (Chiriac et al., 2005, quoted by Mocanu, et al., 2011).

Similarly to drinking-water supply, a major disparity between town and countryside existed also in the sewerage system, in that by far fewer rural settlements were connected to the system.

There are great inter-county differences in what regards the public sewerage network: wherever the drinking-water network is short, the sewerage network is even shorter. There are a few counties where (except for towns) no settlement has a sewerage system, and in the few communes that do have such a system, the pipe length is very short, e.g. Brăila, Călăraşi, Giurgiu, Olt and Teleorman (Table 2).
Looking at the distribution of the sewerage system one finds that 27 out of the 28 Danube Valley towns are connected to the system, with one exception: Dăbuleni in Dolj County. Speaking of communes, there are counties (Brăila, Călăraşi, Galaţi, Giurgiu, Ialomiţa, Olt and Teleorman) in which a sewerage network does not even exist, while in others, few communes benefit from this facility: 2 in Dolj County, 3 in Caraş-Severin, 5 in Constanţa, and 10 in Mehedinţi and Tulcea each (Figure 4). Network length here represents $7.3 \%$ of its total length in Romania.

The length of the sewerage system varies from 0.5 $\mathrm{km}$ in Ghindăreşti Commune (Constanţa County) and $531 \mathrm{~km}$ in Galaţi City (Galaţi County), over 100 $\mathrm{km}$-long networks existing only in county-seat towns

Table 2. Structure of LAU2 connected to the sewerage system, 2014

\begin{tabular}{|l|c|c|c|c|c|}
\hline County & $\begin{array}{c}\text { Urban } \\
\text { LAU 2 }\end{array}$ & $\begin{array}{c}\text { Urban LAU 2 } \\
\text { connected }\end{array}$ & $\begin{array}{c}\text { Rural } \\
\text { LAU 2 }\end{array}$ & $\begin{array}{c}\text { Rural LAU 2 } \\
\text { connected }\end{array}$ & $\begin{array}{c}\text { Total LAU2 } \\
\text { connected }\end{array}$ \\
\hline Brăila & 3 & 3 & 26 & 0 & 3 \\
\hline Caraş-Severin & 1 & 1 & 7 & 3 & 4 \\
\hline Călăraşi & 3 & 3 & 24 & 0 & 3 \\
\hline Constanța & 2 & 2 & 14 & 5 & 7 \\
\hline Dolj & 5 & 4 & 46 & 2 & 6 \\
\hline Galați & 1 & 1 & 3 & 0 & 1 \\
\hline Giurgiu & 1 & 1 & 17 & 0 & 1 \\
\hline lalomița & 2 & 2 & 8 & 0 & 2 \\
\hline Mehedinți & 3 & 3 & 30 & 10 & 13 \\
\hline Olt & 1 & 1 & 15 & 0 & 1 \\
\hline Teleorman & 2 & 2 & 21 & 0 & 2 \\
\hline Tulcea & 4 & 4 & 27 & 10 & 14 \\
\hline TOTAL & 28 & 27 & 238 & 51 & 57 \\
\hline
\end{tabular}




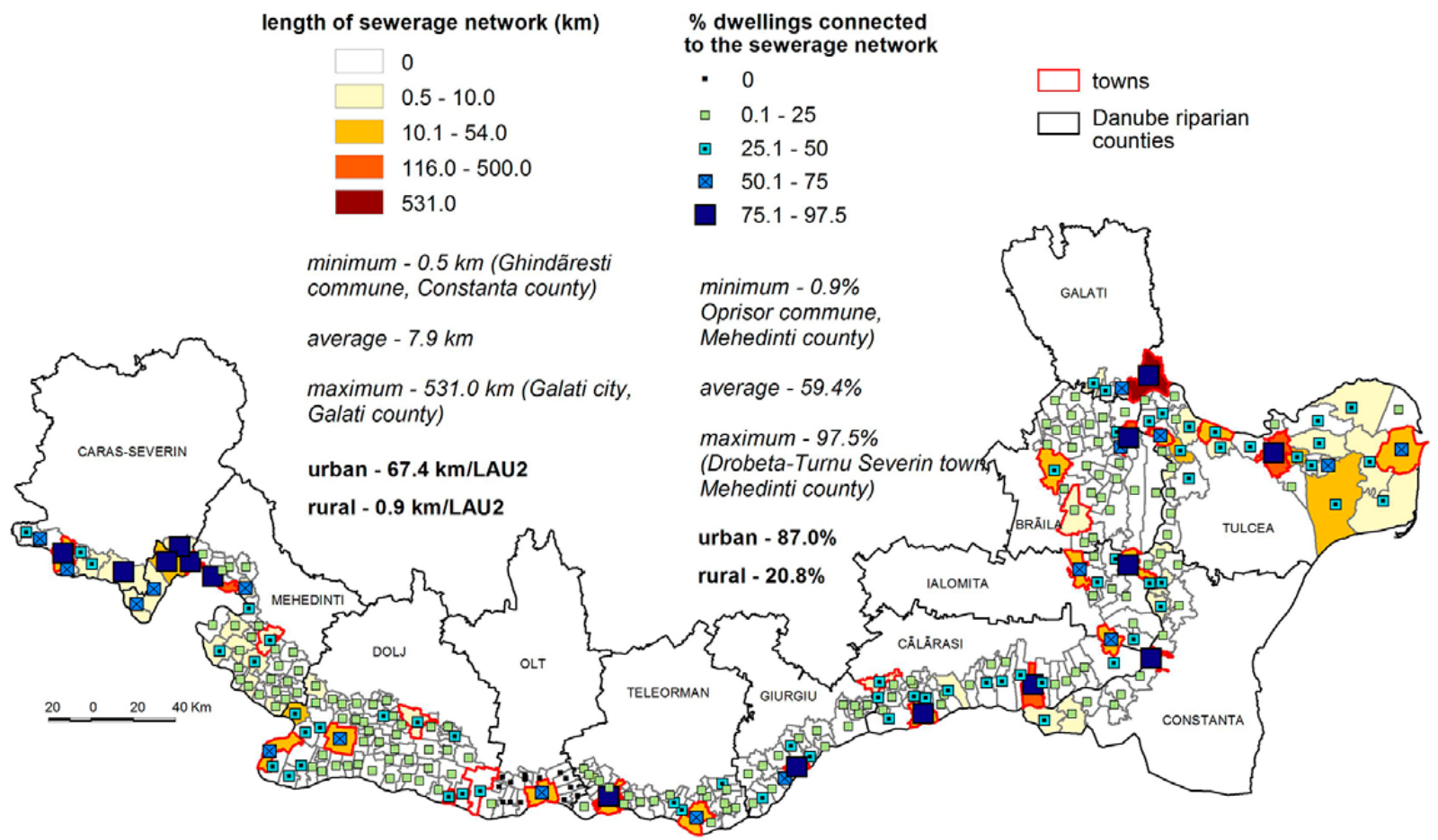

Figure 4. The length of the sewerage network and the dwellings connected to the sewerage network, 2014

with more than 50, ooo inhabitants (Figure 4). By the two milieus, in the rural the average of the sewerage system length is $0.9 \mathrm{~km} / \mathrm{LAU}_{2}$, while in the urban is $67.4 \mathrm{~km} / \mathrm{LAU} 2$.

We may safely say that a sewerage network in the countryside is almost inexistent, and quite unsatisfactory in town, where extension and retechnologisation works are imperative.

The Danube Valley proportion of dwellings connecting to the sewerage network represented $65.1 \%$ of the country's average, that is $0.9 \%-88 \%$ in the countryside and $24.2 \%-97.5 \%$ in town. Out the 237 LAU 2 falling below $59.4 \%$ (the region's average percentage) only 10 rural LAU 2, most of them in Caraş-Severin County stood above the value (Figure 4).

Even more worrying is the situation of the natural gas distribution network in that no locality of the five surveyed counties (Caraş-Severin, Dolj, Olt, Ialomiţa and Constanţa) is connected to the system, while in another five counties (Mehedinţi, Teleorman, Giurgiu, Galaţi and Tulcea), a natural gas network exists only in a few towns. Things look somewhat better in the counties of Brăila and Călăraşi (with 7 and 4 connected localities, respectively) but even here the pipe network is fairly short (50 km), except for the towns of Brăila (211.5 km) and Călăraşi (10o km) (Figure 5). The western Danube-Valley counties (Caraş-Severin, Dolj and Olt) have no gas distribution network, an exception makes Mehedinţi County, where only DrobetaTurnu Severin Town benefit from this utility.

The pipe length in the 23 Danube Valley settlements (14 town and 9 communes) covers $1,335.1 \mathrm{~km}$, that is
$3.5 \%$ of the natural gas network (Figure 5), the natural gas volume distributed for domestic use represents $7.4 \%$ of the distribution level in Romania (2014 data).

The average consumption/capita is of $194.5 \mathrm{~m}^{3} /$ inh./ year, that is 30 times higher than in the countryside $\left(5.9 \mathrm{~m}^{3}\right.$ /inh./year). A number of 10 LAU 2 (8 urban and 2 rural) stand above-average versus the national average value ( $134 \mathrm{~m}^{3}$ /inh./year).

Since in LAU 2 Classes 1 and 3 the values of variables are above-average compared to the Danube Valley mean values, these classes were considered to have a good technical infrastructure (Class 1, notable sharp positive deviation; Class 3, very strong deviation with positive qualitative impact on the infrastructure) (Figure 6).

Highest percentages of dwellings connected to the water supply and sewerage systems, and having the longest sewerage and natural gas distribution pipes registered Galaţi, Brăila and Tulcea cities.

Also with a very high-quality technical infrastructure are a few better economically- developed rural LAU2, located close to town (e.g. Chişcani near Brăila). Apart from small and middle towns - some of them municipia (e.g. Moldova Nou, Orşova, Calafat, Băileşti, Dăbuleni, Corabia, Călăraşi, Feteşti, Cernavodă, Ianca, Isaccea, and Sulina), the high technical- infrastructure category includes also rural $\mathrm{LAU}_{2}$ which are tourist destinations (Mahmudia in the Danube Delta; the Iron Gate Defile in the mountain region - e.g. Dubova, Pojejena, Şviniţa, and Coronini) or some located close to big Danubian cities (Cazaşu near Brăila and Şendreni near Galaţi). 
Technical-urbanistic infrastructure in the Romanian Danube Valley.

Urban vs. rural territorial disparities

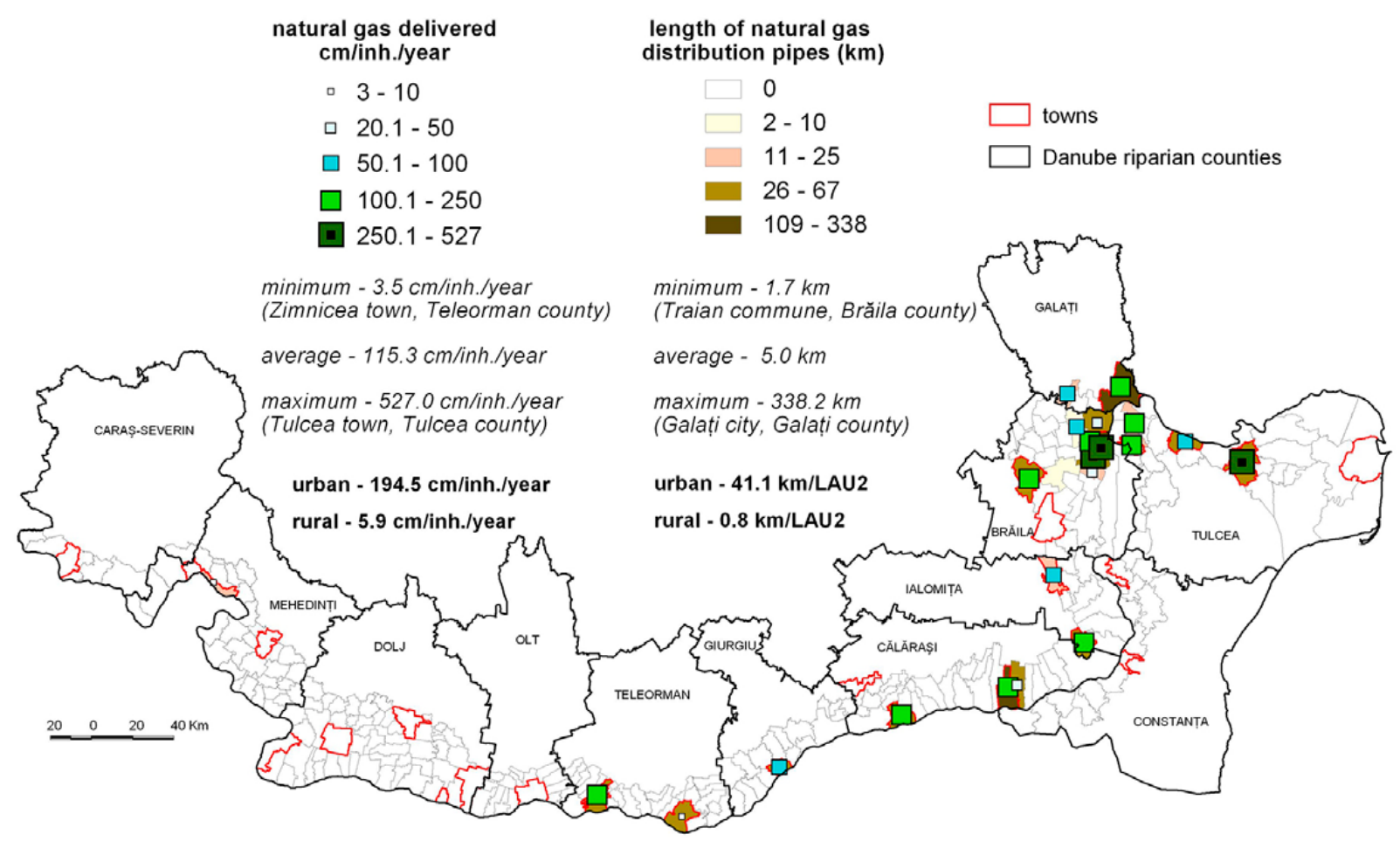

Figure 5. The length of the natural gas network, 2014

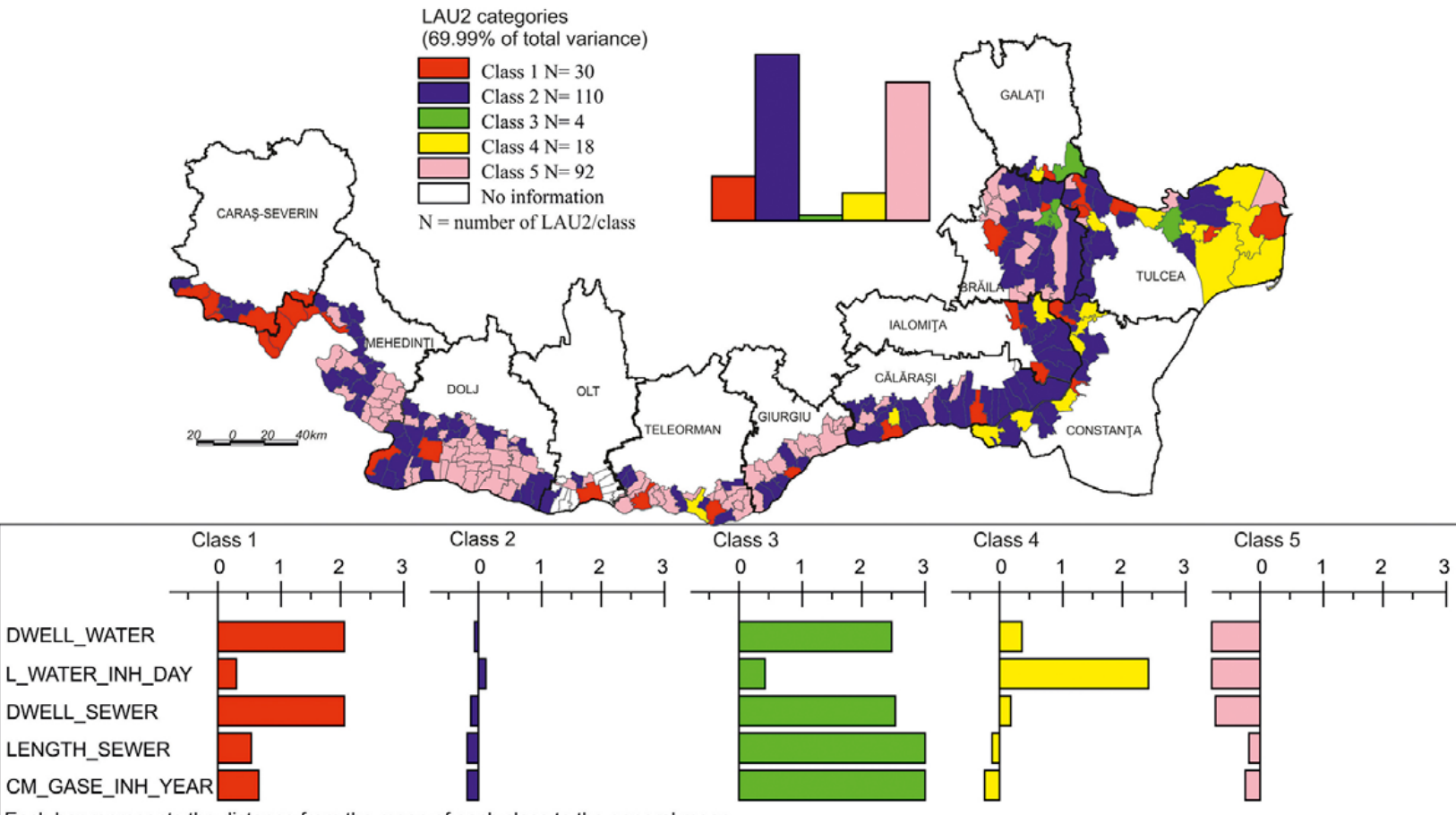

Each bar represents the distance from the mean of each class to the general mean

This distance is expressed in standard deviation number of each variable.

- Class 1 groups small and middle towns in which the percent of dwellings connected to the water-supply network and sewerage system exceeds by far the study-area average;

- Class 2 groups rural settlements in which all variables have a value-class to the study-area average;

- Class 3 groups 4 LAU 2, of which are large towns where the value of variables is by for greater than the study-area average, except for water consumption/inh. which is slightly above the study-area average;

- Class 4 groups rural settlements in which water consumption/inh. is high, while the other variables have a value close to the study-area average:

- Class 5 groups rural settlements in which the value of all variables is below the study-area average.

Figure 6. Types of LAU2 in terms of technical infrastructure quality, 2014

Source: Population and Housing Census 2011, TEMPO Online, National Institute of Statistics Philcarto Software (http://philcarto.free.fr) 
The values of the 110 Class 2 rural LAU 2 variables are close to the study-area average. However, they register a very weak positive deviation, having a positive impact on technical- infrastructure quality only in the case of litres/inh./day. All the other variables show a weak negative deviation, having a negative impact on technical infrastructure quality.

Speaking of this class, one should have in view that the mean values calculated for the Romanian Danube Valley are lower than the national ones (e.g. the average percentage of dwellings in the Romanian Danube Valley connected to the water supply network is $60.8 \%$ vs. the national average of $66.7 \%$, while those connected to the sewerage system is $59.4 \%$ vs. the national average of $65.1 \%$ ). This relation indicates that Class 2 LAU 2 components are close to the average value of the study-area, which is not quite the case of the technical-infrastructure quality. That is why, the territorial units studied ( $42 \%$ of all the Danube Valley administrative units) were considered to have a low-quality technical-infrastructure.

Class 4 - rural LAU 2 (6.7\% of all territorial units in the Valley sector) occur especially in the eastern part of this sector, with twice as many in the Danube Delta. What differentiates this class is water consumption/ capita, the values showing a very strong positive deviation that has a beneficial impact on the technical infrastructure quality level.

Class 5 groups 92 rural settlements $(34.5 \%$ of all the Danubian LAU 2), the value of all their variables being below the Valley average. Here, the technical infrastructure quality level is very low, because all variables are weak, they have a notable negative deviation and a negative impact on all the analysed aspects. The majority LAU 2 in this Class have no sewerage system or natural gas supply either (Figure 6).

\section{Conclusions}

At national level, one of the weaknesses in the development of utilities is the poor access of settlements to the water supply (22,4\% of all $\mathrm{LAU}_{2}$ are unconnected) and sewerage systems $\left(73,4 \%\right.$ of all $\mathrm{LAU}_{2}$ are unconnected), deficient drinking-water quality, some settlements missing a sewerage and waste-water purification system (over $71 \%$ of this water is not at all purified or insufficiently so).

Although the Danube Vally region is a rich water source, yet many settlements have no access to drinking water. Looking at the area's characteristics we see that all LAU2 in the counties of Constanţa, Ialomiţa, Brăila and Tulcea are connected to the public watersupply system; at the end of 2014, all of the region's towns had drinking-water installations; $30.7 \%$ without such facilities were in the countryside; the $82 \mathrm{LAU}_{2}$ with no drinking-water network were in the counties of Dolj, Călăraşi, Mehedinţi, Olt, Giurgiu and Teleorman; $77 \%$ of all Danubian LAU 2 had no sewerage system either. In view of it, the Danube Valley population runs very serious health risks, water-consumption quality is directly affecting people's health; besides, the quality of surface and ground waters is impaired the discharge of impure waste waters. Unfortunately, people in the Danube Valley and in other places of Romania take water from wells and springs to drink. Usually, these sources are inappropriate physicalchemically and microbiologically, which contributes to increasing general and infant morbidity caused by infections and parasitic disease.

Many Danube Valley urban, and especially rural communities, have no local drinking-water and sewerage infrastructure, a situation contributing to maintaining, among others, the vicious circle of poverty. Unconnecting some settlements to the public utilities infrastructure investments is a drawback to in the local economies, accounting in part for inter-regional development disparities between the Danube Valley and the other regions of Romania; as well as between village and town, and the big Danubian centres, on the one hand and middle and small towns in the region, on the other.

At present, the local authorities are keen on sustaining the development of settlements, first of all by improving and updating the infrastructure, in order to make them more attractive for the locals and for potential investors alike.

\section{Acknowledgements}

The research for this paper was performed under the Institute of Geography's research plan (the priority research project of the Romanian Academy on the "Geographical Study of the Romanian Danube Valley").

\section{References}

Androniceanu, A. 2002. News in public management, Editura Economică, Bucharest (in Romanian).

Antonescu, D. 2014. Quantitative and qualitative aspects regarding housing in the European Union and Romania. Available ata: https://mpra.ub.unimuenchen.de/57859/Munich Personal RePEc Archive (MPRA) Paper No. 57859, https://mpra.ub.unimuenchen.de/57859/1/MPRA_paper_57859.pdf.

Babucea, A.G., Rabonţu, C.I. 2015. Public services and their role in society and the economy, Annals of the "Constantin Brâncuşi” University of Târgu Jiu, Letter and Social Science Series 1, 58-64.

Benzécri, J.-P. 1982. Construction of a Hierarchical Ascendant Classification by searching in chain of 
reciprocal nearest neighbors (in French with English summary), Cahiers de l'analyse des données, 72, 209-218.

Bruynooghe, M. 1977. Novel methods for automatic classification of numerous taxonomic data (in French with English summary), Statistique et analyse des données 2(3), 24-42.

Chiriac, D., Humă, C., Tudor, C. 2001. Socio-economic impact of water on the life quality in Romania (in Romanian), Calitatea Vieţii, XII, 1-4, 95-116.

Chiriac, D., Geicu, A., Humă, C., Bleahu, A. 2005. Socio-economic effects of the drought on the communities life quality in Romania (in Romanian), Calitatea Vieţii 16(3-4), 313-331.

Damian, N. 2013. The Danube Delta geographical environment and social risk factors, Editura Universitară, Bucharest, 264 pp. (in Romanian with English summary).

Dumitrache, L. 2004, Health of the population of Romania. A geographical approach (in Romanian with English summary), Univers Enciclopedic, Bucharestm (in Romanian with English summary).

Dumitrescu, B. 2008. One-industry towns in Romania between forcible industrialisation and economic decline, Editura Universitară, Bucharest, 301 pp. (in Romanian with English summary).

Eberhardt R., Pegram G. 200o. The water sector. a position paper, Deutsche Gesellschaft für Technische Zusammenarbeit, GmbH, World Wide Fund for Nature, Development Bank of Southern Africa.

ENVIS Centre on Human Settlements 2009. Monograph in Quality of Life Indicators. Department of Environmental Planning, School of Planning and Architecture. New Delhi.

EU European Commission 2014. Green Paper. Available at: http://ec.europa.eu/green-papers/

Gadysz, R. 2009. The state of sewage system economics in rural areas in Poland, Iinfrastructure and ecology of rural areas, 7, Polska Akademia Nauk, Oddzia w Krakowie, 57-68.

Günther, I., Günther, F. 2011. Water and Sanitation to Reduce Child Mortality. The Impact and Cost of Water and Sanitation Infrastructure, Policy Research Working Paper, no. 5618, The World Bank, Development Economics Prospects Group.

Ianoş, I. 2000. Territorial systems. Editura Tehnică, Bucharest, 197 pp. (in Romanian with English summary.

Koeck, R. (eds.) 2012. Climate Change and Impacts on Water Supply “CC-WaterS”. Available at: http:// www.ccwaters.eu/downloads/CC WaterS_Project_ Monography_final.pdf.

Lieske, S.N., McLeod, D.M., Coupal, R.H., 2015. Infrastructure development, residential growth and im- pacts on public service expenditure. Applied Spatial Analysis and Policy 8(2), 113-130.

Mitrică, B., Mocanu, I. 2011. Drinking water supply and consumption territorial disparities in the Timiş Plain, Analele Universităţii din Oradea, Geographie 16(2), 239-247.

Mocanu, I., Dumitraşcu, M. Mitrică, B., Popovici, A. 2011. Drinking water infrastructure in Oltenia Plain in the last decade. Territorial distribution and quantitative aspects of production and consumption, Forum Geografic. Studii şi cercetări de geografie şi protecţia mediului 10(2), 364-371.

Negruţ, V., 2008. The legal regime of the public utilities services, Transylvanian Review of Administrative Sciences 1(21), 99-104.

Plumb, I., Androniceanu, A., Abaluţă O. 2003. Management of the public services. Editura ASE, Bucharest. (in Romanian with English summary)

Policy Brief on Water Quality (PBWQ) 2011. UN-Water. Available at: http://www.unwater.org/downloads/waterquality_policybrief.pdf

Qilin, L., Dueñas-Osorio, L., Raciny, I. 2009. Sustainable water infrastructure for improving public health protection. A look at centralized, decentralized and hybrid water systems. Available at: http:// shellcenter.rice.edu/Content.aspx?id=59

Regional Development Plan for the South-Est Development Region 2014-2020, 2014. South-East Regional Development Agency. (in Romanian)

Regional Development Plan for the South-West Oltenia Development Region 2014-2020, 2014. SouthWest Oltenia Regional Development Agency. (in Romanian)

Regional Development Plan for the South-East Development Region 2014-2020, 2015. South-East Regional Development Agency. (in Romanian)

Regional Development Plan for the South-Muntenia Development Region 2014-2020, 2015. South-Muntenia Regional Development Agency. (in Romanian)

Regional Development Plan for the South-West Oltenia Development Region 2014-2020, 2015. SouthWest Oltenia Regional Development Agency. (in Romanian)

Romania's Territorial Development Strategy 20202035, 2015. Ministry of Regional Development and Public Administration. Available at: www.sdtr.ro (in Romanian)

Population and Dwellings Census 2011. National Institute of Statistics, Bucharest.

Săgeată R., Persu, M. 2013. Cross-border co-operation Euroregions in the Romanian Danube border-zone, Revue Roumaine de Géographie/Romanian Journal of Geography 57(2), 129-138 pp. 
Săgeată, R., Dumitrescu, B., Damian, N. 2010. CrossBorder Cooperation in the Danube-Lined Romanian/Bulgarian Border Space. Geographical Considerations, Geographica Pannonica 14(2), 67-75.

Teodorescu, Camelia, 2005. The analysis of the mean net income of the occupied active population within Oltenia's counties nowadays, Forum Geografic. Studii şi cercetări de geografie şi protecţia mediului 4, 92-95.

Vâlceanu, D., Tămârjan, D. 2011. The quality of the living conditions in Romania, in the postaccesion period to EU (in Romanian with English summary), Urbanism. Architecture. Constructions 3(2), 35-50.

Vâlceanu, D., Zulaica, L. 2012. Habitat quality index instrument for assessing the quality of urban habitat (in Romanian with English summary), Urbanism. Architecture. Constructions 3(4), 45-56.

Vasile, M., Tufă, L., Preoteasa, A.M., Precupeţu, I., Popescu, R., Neagu, G., Mihalache, F., Mihăilescu, A., Mărginean, I., Dumitru, M. 2010. Life quality in Romania (in Romanian), Inovaţia Socială 3(1). Available at: http://www.inovatiasociala.ro/arti$\mathrm{col} / 51 /$

Vîrdol, D. 2009. Socio-economic dynamics of the small towns in the Romanian Danube Valley (in Romanian). Available at: http://www.unibuc.ro/ studies/Doctorate2009Noiembrie/Virdol\%20\%20 Daniel\%20-\%2oDinamica\%2oSocial-Economi-
ca\%20a\%2oOraselor\%2oMici\%2odin\%2oValea\%2o Dunarii\%2oRomanesti/rezumat_DanielVIRDOL. pdf.

Voicu, B., Voicu, M. 2005. Access to public utilities in Romania (in Romanian with English summary), Revista Calitatea vieţii 1-2, 21-49.

Water Quality for Ecosystems and Human Health (WQEHH) 2008. 2nd edition, UNEP, ERCE, UNESCO. Available at: http://www.unwater.org/wwd1o/ downloads/water_quality_human_health.pdf

World Water Day "Clean Water for a Healthy World" (CWHW) 2010. UN-Water, UNEP, FAOWater. Available at: http://www.unwater.org/wwd1o/ downloads/WWD2010_LOWRES_BROCHURE_ EN.pdf

Zhou, J., Liu, Y.J. 2015. The method and index of sustainability assessment of infrastructure projects based on system dynamics in China, Journal of Industrial Engineering and Management 8(3), 10021019.

\section{Internet references}

Internet 1: Institutul Naţional de Statistică (National Institute of Statistics). TEMPO-online database. Available at: http://statistici.insse.ro/

Internet 2: European Union Strategy for Danube Region. Available at: www.danube-region.eu, http:// philcarto.free.fr 